\title{
ANALISIS DETERMINASI MIGRASI TIDAK PERMANEN ANTAR DAERAH DI PROVINSI SUMATERA BARAT
}

\author{
Salfadri Syamsuddin \\ Fakultas Ekonomi Universitas Ekasakti, Padang, Indonesia \\ Email: salfadrisyamsuddin@gmail.com
}

\begin{abstract}
This study aims to reveal and analyze the influence of variables of age, education level, employment status and transportation costs to the destination area to non-permanent migration between regions in the province of West Sumatra. This study uses primary data derived from surveys of people who carry out non-permanent migration between regions in West Sumatra Province. The number of samples in this study were 1040 people. This research uses multiple regression analysis. The results of this study found that the age, employment status and transportation costs to the destination area significantly influence the intermittent migration between regions in West Sumatra Province. The level of education has no significant effect on non-permanent migration between regions in West Sumatra Province.
\end{abstract}

Keywords: spatial interaction model; non-permanent migration; inter-regional migration; population mobility.

\begin{abstract}
ABSTRAK
Penelitian ini bertujuan untuk mengungkapkan dan menganalisis pengaruh variabel umur, tingkat pendidikan, status pekerjaan dan biaya transportasi ke daerah tujuan terhadap migrasi tidak permanen antar daerah di provinsi Sumatera Barat. Penelitian ini menggunakan data primer yang berasal dari survey kepada masyarakat yang melakukan migrasi tidak permanen antar daerah di Provinsi Sumatera Barat. Jumlah sampel dalam penelitian ini adalah 1040 orang. Penelitian ini menggunakan analisa regressi berganda. Hasil penelitian ini menemukan bahwa variabel umur, status pekerjaan dan biaya transportasi ke daerah tujuan berpengaruh secara signifikan terhadap migrasi tidak permanen antar wilayah di Provinsi Sumatera Barat. Tingkat pendidikan tidak berpengaruh secara signifikan terhadap migrasi tidak permanen antar wilayah di Provinsi Sumatera Barat.
\end{abstract}

Kata kunci : model interaksi spasial; migrasi tidak permenen; migrasi antar daerah; mobilitas penduduk. 


\section{PENDAHULUAN}

Interaksi spasial merupakan pergerakan atau komunikasi antara wilayah yang berbeda. Menurut Ullman dalam (Yunus, 2010) pergerakan atau komunikasi antara wilayah tersebut bisa berupa aliran komoditas (aliran perdagangan antar wilayah), informasi dan mobilitas penduduk (migrasi). Semakin meningkat perdagangan antar suatu daerah akan semakin meningkat pula mobilitas penduduknya (Casi, 2006). Selanjutnya menurut (Mantra, 1985) mobilitas penduduk dapat dibagi menjadi 2 bentuk yaitu: mobilitas permanen (migrasi) dan non permanen (sirkuler). Migrasi adalah perpindahan penduduk dari suatu wilayah ke wilayah lain dengan maksud untuk menetap di daerah tujuan. Sedangkan mobilitas non permanen ialah pergerakan penduduk dari suatu tempat ke tempat lain dengan tidak ada niatan untuk menetap di daerah tujuan.

Selanjutnya (Mantra, 2000) mengelompokkan migrasi menjadi 3 kelompok berdasarkan bentuk mobilitas, batas wilayah dan batas waktu seperti dapat kita lihat pada Tabel 1 berikut ini:

Tabel 1.

\section{Bentuk-bentuk Mobilitas Penduduk}

\begin{tabular}{|c|c|c|}
\hline Bentuk Mobilitas & $\begin{array}{l}\text { Batas } \\
\text { Wilayah }\end{array}$ & Batas Waktu \\
\hline 1. Ulang-alik (commuting) & $\begin{array}{l}\text { Dukuh } \\
\text { (dusun) }\end{array}$ & $\begin{array}{l}6 \text { jam atau lebih dan kembali pada hari yang } \\
\text { sama }\end{array}$ \\
\hline $\begin{array}{l}\text { 2. Menginap/mondok di daerah } \\
\text { tujuan }\end{array}$ & $\begin{array}{l}\text { Dukuh } \\
\text { (dusun) }\end{array}$ & Lebih dari satu hari tetapi kurang dari 6 bulan \\
\hline $\begin{array}{l}\text { 3. Permanen/menetap di } \\
\text { daerah tujuan }\end{array}$ & $\begin{array}{l}\text { Dukuh } \\
\text { (dusun) }\end{array}$ & 6 bulan atau lebih menetap di daerah Tujuan \\
\hline
\end{tabular}

Dari Tabel 1 dapat kita lihat bahwa batasan wilayah dari suatu mobilitas (migrasi) penduduk menurut Ida Bagus Mantra paling dekat adalah antar dukuh 
(dusun) dan batasan waktu yang paling pendek adalah 6 jam. Jadi penduduk yang melakukan perjalanan 6 jam atau lebih sudah dapat dikatakan melakukan mobilitas penduduk (migrasi). Dari Tabel 1 di atas juga dapat kita simpulkan bahwa terdapat 3 bentuk mobilitas penduduk yaitu: ulang alik (commuting), migrasi tidak permanen dan migrasi permanen.

Ketiga jenis mobilitas penduduk antar daerah seperti yang diperlihatkan oleh Tabel 1 di atas juga terjadi di Provinsi Sumatera Barat. Mobilitas penduduk antar daerah di Provinsi Sumatera Barat ada yang menggunakan kendaraan pribadi dan menggunakan angkutan umum. Mobilitas penduduk yang dapat dilihat dengan jelas adalah mereka yang melakukan migrasi tidak permanen menggunakan angkutan umum berupa bus antar kota dapat dilihat pada Tabel 2.

Tabel 2.

Jumlah Penumpang dari Kota Padang ke berbagai Kabupaten/Kota di Provinsi Sumatera Barat Tahun 2018

\begin{tabular}{lc}
\hline \multicolumn{1}{c}{ Daerah Asal - Tujuan } & Penumpang (orang) \\
\hline Padang - Bukittinggi & $7.680,00$ \\
Padang - Payakumbuh & $3.360,00$ \\
Padang - Solok & $4.480,00$ \\
Padang - Sawahlunto & $1.600,00$ \\
Padang - Kab. Pdg Pariaman & $7.520,00$ \\
Padang - Pariaman & $3.776,00$ \\
Padang - Kab. Agam & $4.352,00$ \\
Padang - Kab. Pasaman & $1.147,00$ \\
Padang - Kab. Pasaman Barat & $3.958,00$ \\
Padang - Kab. 50 Kota & $2.696,00$ \\
Padang - Kab. Tanah Datar & $5.146,00$ \\
Padang - Kab.Solok & $1.280,00$ \\
Padang - Kab.Solok Selatan & $3.456,00$ \\
Padang - Kab. Sijunjung & $2.304,00$ \\
Padang - Kab. Pesisir Selatan & $8.368,00$ \\
Padang - Kab.Dharmasraya & 2176,00 \\
\hline
\end{tabular}

Sumber : BPS Sumatera Barat, Sumbar Dalam Angka 2018 
Dalam Tabel 2 terlihat bahwa jumlah penumpang dan volume angkutan menurut trayek yang terbesar adalah antara Padang dengan Kabupaten Pesisir Selatan. Hal ini karena jaraknya yang berdekatan dan akses dari Kabupaten Pesisir Selatan ke kabupaten/kota lain harus melalui Padang. Peringkat kedua adalah jumlah penumpang antara Padang dengan Bukittinggi. Hal ini dapat dipahami karena kedua kota itu adalah pusat kegiatan ekonomi yang terbesar di Propinsi Sumatera Barat. Padang sebagai ibukota Propinsi Sumatera Barat merupakan pusat pemerintahan dan pusat pendidikan dan sekaligus pusat perdagangan, sedangkan Bukittinggi walaupun bukan yang terbesar jumlah penduduknya, akan tetapi karena posisinya yang strategis (terletak di persimpangan jalan menuju kota Pekan Baru, Medan dan Palembang). Dengan letaknya yang strategis ini maka Bukittinggi menjadi pusat perdagangan grosir di Provinsi Sumatera Barat. Sementara posisi ketiga jumlah penumpang terpadat adalah antar Padang dengan Kabupaten Padang Pariaman. Hal ini juga karena letak wilayahnya yang berdekatan.

Dalam Tabel 2 juga terlihat bahwa Padang sebagai ibukota Provinsi Sumatera Barat memiliki trayek angkutan ke seluruh kabupaten/kota lainnya di provinsi Sumatera Barat. Dengan adanya sarana dan prasarana transportasi yang lengkap, dan didorong oleh adanya perbedaan sumber daya alam, perbedaan harga, perbedaan selera masyarakat dan faktor-faktor lainnya, akan meningkatkan aktivitas perdagangan dan mobilitas penduduk antar wilayah (Salfadri; Abubakar Hamzah; B S Nazamuddin; Sofyan Syahnur, 2015)

Penelitian tentang migrasi tidak permanen di Indonesia juga telah dilakukan oleh para ahli diantaranya adalah: (Widaryatmo, 2009),yang menemukan bahwa 
semakin tinggi tingkat pendidikan, semakin cenderung untuk komutasi; semakin rendah tingkat pendidikan, semakin cenderung untuk sirkulasi. Kemudian (Putrawan, I, W., 2015), menggunakan analisis regresi logistik untuk menemukan kontribusi dan bentuk hubungan antara karakteristik dan keputusan mereka untuk bekerja dengan mobilitas non-permanen. Karyawan laki-laki yang bekerja di area layanan dengan usia yang lebih muda, upah lebih tinggi dan pendidikan yang lebih tinggi cenderung untuk memutuskan bekerja dengan mobilitas non-permanen di sekitar Sarbagita Provinsi Bali. Kebutuhan ekonomi orang menikah tidak memberikan kontribusi yang signifikan untuk memutuskan bekerja dengan mobilitas non-permanen di sekitar daerah Sarbagita Provinsi Bali.

Penelitian tentang migrasi penduduk Provinsi Sumatera Barat telah dilakukan oleh beberapa ahli diantaranya adalah: (Bachtiar, 1990) yang meneliti faktor-faktor apa yang mempengaruhi kemungkinan orang untuk pindah dari Kabupaten ke Kotamadya di Propinsi Sumatera Barat. Bactiar menemukan bahwa Perbedaan potensi sosial ekonomi daerah asal dan daerah tujuan mempengaruhi keinginan seseorang untuk pindah melalui persepsinya terhadap kondisi tersebut. Persepsi ini akan positif bila harapan untuk mendapatkan kehidupan yang lebih baik tinggi di daerah tujuan. Penelitian lain adalah (Karib, 1992) yang meneliti tentang faktor-faktor yang mempengaruhi migrasi keluar penduduk Koto Gadang. Kemudian (Sasmi, Cici \& Bachtiar, 2014) juga meneliti faktor-faktor mempengaruhi migrasi masuk ke Kota Padang. Hasil dari penelitian mereka menunjukan bahwa umur, status perkawinan, pendidikan dan pendapatan berpengaruh positif dan signifikan terhadap keputusan penduduk untuk melakukan 
migrasi masuk ke Kota Padang. Sedangkan jenis kelamin tidak berpengaruh terhadap keputusan penduduk untuk melakukan migrasi masuk ke Kota Padang. Ketiga penelitian meneliti tentang faktor-faktor yang mempengaruhi migrasi permanen yang dilakukan oleh masyarakat di Provinsi Sumatera Barat, sedangkan penelitian tentang migrasi tidak permanen sepengetahuan penulis belum pernah dilakukan.

Mobilitas Penduduk atau arus migrasi dipengaruhi oleh 4 faktor (Mantra, 1985), yaitu:1). Faktor individu, seperti kebiasaan yang ada dalam suatu kelompok (suku) yang memang suka merantau. Sebagai contoh dalam suku minangkabau di Provinsi Sumatera Barat ada kebiasaan penduduknya untuk merantau ke luar daerah asalnya. 2). Faktor yang terdapat didaerah asal, seperti keterbatasan kepemilikan lahan, upah yang rendah, waktu luang (time lag) antara masa tanam dengan masa panen, sempitnya lapangan pekerjaan di desa dan terbatasnya jenis pekerjaan di desa. 3). Faktor di daerah tujuan, seperti tingkat upah yang tinggi, luasnya lapangan pekerjaan yang beraneka ragam di daerah tujuan migrasi. 4). Rintangan antara daerah asal dengan daerah tujuan, seperti: sarana transportasi, topografi desa ke kota dan jarak desa kota. Keempat faktor tersebut dapat digambarkan dengan Gambar 1. 
Gambar 1.

Faktor-Faktor Yang Mempengaruhi Mobilitas Penduduk

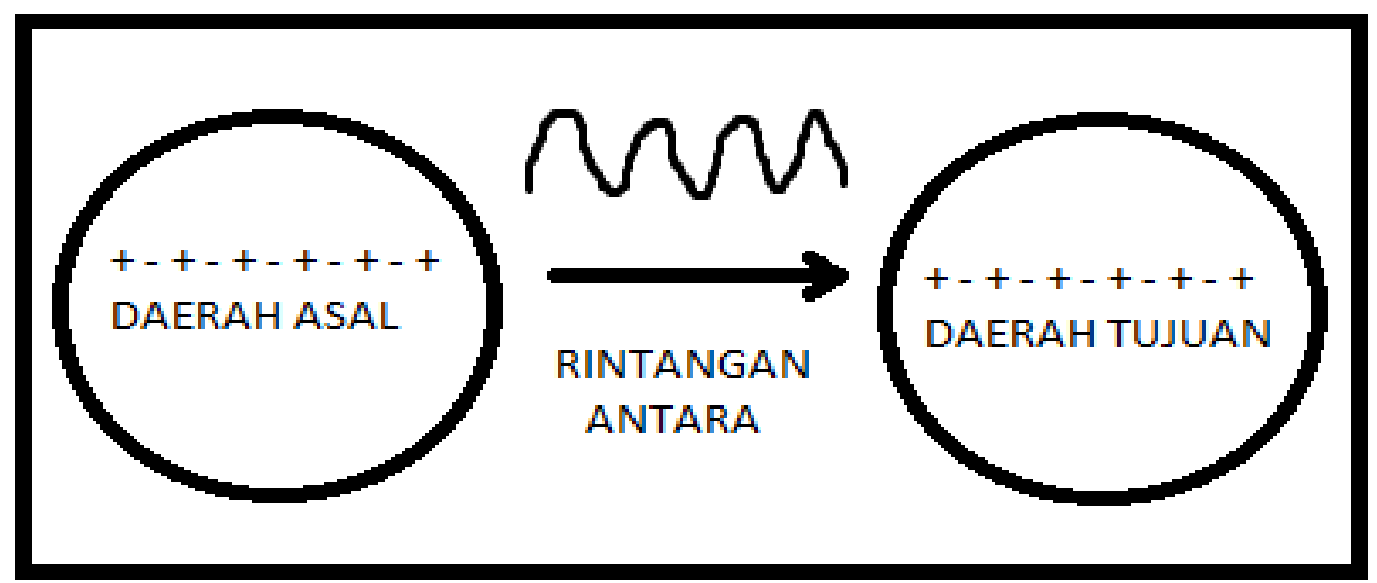

Sumber : Mantra, 1985: 18,1dengan sedikit perubahan

(Todaro, M.P., 2003) mengemukakan teori tentang migrasi desa-kota yang mengasumsikan bahwa migrasi desa-kota pada dasarnya merupakan suatu fenomena ekonomi. Oleh karena itu, keputusan untuk melakukan migrasi juga merupakan suatu keputusan yang telah dirumuskan secara rasional. Model migrasi (Todaro, M.P., 2003) memiliki empat pemikiran dasar sebagai berikut: 1). Migrasi desa-kota dirangsang, terutama sekali, oleh berbagai pertimbangan ekonomi rasional yang langsung berkaitan dengan keuntungan atau manfaat dan biaya-biaya relatif migrasi itu sendiri. 2). Keputusan untuk bermigrasi tergantung pada selisih antara pendapatan yang diharapkan di kota dan tingkat pendapatan aktual di pedesaan. Maksudnya ada dua variabel pokok, yaitu selisih upah aktual dikota dan di desa, serta besar atau kecilnya kemungkinan mendapatkan pekerjaan di perkotaan yang menawarkan tingkat pendapatan sesuai dengan yang diharapkan.3). Kemungkinan mendapatkan pekerjaan di perkotaan berkaitan langsung dengan tingkat lapangan pekerjaan di perkotaan, sehingga berbanding terbalik dengan tingkat pengangguran di perkotaan. 4).Tingkat migrasi melebihi tingkat 
pertumbuhan lapangan kerja di kota bukanlah suatu kemungkinan, akan tetapi logis dan telah terjadi, begitu pula besarnya perbedaan upah antara desa dengan kota. Tingginya tingkat pengangguran di kota suatu hal yang tidak dapat dielakan. Hal ini disebabkan oleh ketidakseimbangan pertumbuhan ekonomi yang terdapat di desa dan di kota.

Migrasi antara suatu daerah dengan daerah lain dapat pula dijelaskan dengan model gravitasi. Model gravitasi adalah salah satu model yang paling sukses secara empiris untuk menganalisis interaksi spasial. Konsepnya begitu alami yang kelihatannya dapat digunakan untuk menjelaskan hubungan ekonomi antara sepasang unit geografis dengan atau tanpa kata "gravitasi” (Deardorff, 1998)

Model gravitasi mengasumsikan bahwa aliran antara dua negara berbanding lurus dengan ukurannya (populasi atau PDB) dan berbanding terbalik dengan jarak fisik di antara mereka (mirip dengan hukum gravitasi Newton). Karena yang terbaru ketersediaan data migrasi bilateral (mis. dua arah, negara ke negara), model gravitasi menjadi lebih sering digunakan dalam konteks arus migrasi. Ini memungkinkan pemahaman yang lebih baik tentang faktor-faktor penentu migrasi saat menilai dampak kebijakan. Peningkatan lebih lanjut dalam penerapan set data baru akan meningkatkan kegunaan model gravitasi di konteks kebijakan migrasi. (Ramos, 2016)

Model gravitasi ini pada mulanya digunakan untuk menghitung banyaknya kendaraan (trip) antara satu tempat dengan tempat lainnya yang berada dalam satu sistem dimana perubahan pada salah satu wilayah akan berpengaruh pada wilayah lainnya (Tarigan, 2005) . Rumus dasar untuk menghitung banyaknya perjalanan 
(trip) antara $\mathrm{Pi}$ dan $\mathrm{Pj}$ yaitu trip yang berasal dari wilayah i dan memilih tujuan wilayah $\mathrm{j}$ adalah :

$I_{i j}=k \frac{P_{i} P_{j}}{d_{i j}^{b}}$

Dimana :

$\mathrm{I}_{\mathrm{ij}} \quad=$ Jumlah trip wilayah $\mathrm{i}$ dengan tujuan wilayah $\mathrm{j}$

$\mathrm{P}_{\mathrm{i}} \quad=$ Jumlah Penduduk wilayah $\mathrm{i}$

$\mathrm{P}_{\mathrm{j}} \quad$ = Jumlah Penduduk wilayah $\mathrm{j}$

$\mathrm{d}_{\mathrm{ij}}^{\mathrm{b}}=$ Jarak antara wilayah i ke wilayah $\mathrm{j}$, dinyatakan dalam waktu tempuh (menit).

$\mathrm{b}=$ Pangkat dari $\mathrm{d}_{\mathrm{ij}}$ menggambarkan cepatnya jumlah trip menurun seiring dengan perubahan jarak. Nilai b dapat dihitung, apabila tidak maka sering digunakan $b=2$.

$\mathrm{k}=$ sebuah bilangan konstanta berdasarkan pengalaman, juga dapat dihitung seperti b.

Pendekatan fungsional dasar daripada model gravitasi dikemukakan oleh Jan Tinbergen pada tahun 1963, dalam (Bobkova, 2012) Bentuk fungsi yang dikemukakannya diterapkan secara luas sehingga disebut fungsi "interaksi sosial" karena bisa diterapkan pada migrasi, pariwisata dan investasi langsung. Model gravitasi mulai menjadi perhatian sebagai alat analisis interaksi sosial dan ekonomi setelah adanya hasil penelitian Carey dan Revenstain pada abad ke 19 yang meneliti tentang asal tempat tinggal migran yang datang ke berbagai kota besar di Amerika (Tarigan, 2005).

Sekarang ini model gravitasi untuk menganalisa aliran penduduk (migrasi) telah dikembangkan dengan memasukan berbagai variable yang mempengaruhi seorang penduduk untuk melakukan migrasi. Variabel yang mempengaruhi keputusan seseorang untuk bermigrasi adalah: tingkat pendidikan, jumlah anak 
yang belum sekolah, jumlah anak yang sekolah, luas lahan di desa, sarana jalan aspal yang menghubungkan desa-kota, dan adanya fasiltas komunikasi ke desa. (Zhao, 1999). (Hossain, 2001) menambahkan beberapa variabel lain yang mempengaruhi seseorang untuk memutuskan bermigrasi ke daerah lain yaitu : kepemilikan lahan, jabatan, jumlah anggota keluarga, jenis kelamin, laki-laki usia dewasa dan ukuran keluarga. Demikian pula (Zhu, 2002) menambahkan variabel independen lain yaitu : umur, status perkawinan sebelum bermigrasi, jumlah kakak dan adik, status anak tertua, status pekerjaan dan pendapatan per bulan yang mempengaruhi keputusan seorang individu dalam bermigrasi. Selanjutnya (Chotib, 2002) juga menambahkan kesempatan kerja, tingkat pengangguran, krisis ekonomi, kenaikan harga dan pertumbuhan ekonomi sebagai variabel independen yang mempengaruhi migrasi.

(Badiani, R., \& Safir, A., 2008) menambahkan variabel musim penghujan, pekerjaan bertani, pekerja non pertanian, tingkat upah pertanian, jumlah laki-laki dewasa dalam keluarga, rata-rata upah migrasi, rata-rata upah pertanian, variabel dummy untuk waktu, dan variabel dummy desa sebagai variabel yang mempengaruhi terjadinya migrasi sementara. Sementara itu (Bachmeier, J, D., \& Bean, 2009) juga menambahkan variabel tingkat migrasi tahun sebelumnya, skor kematangan perkampungan, jumlah penduduk tahun sebelumnya, sewa rata-rata tahun sebelumnya, upah rata-rata sejam tahun sebelumnya, jumlah tenaga kerja yang lahir di daerah tujuan migrasi sebagai variabel yang mempengaruhi migrasi. 


\section{METODE PENELITIAN}

Ruang lingkup penelitian ini adalah kabupaten/kota di Provinsi Sumatera Barat. Jumlah populasi tidak diketahui dan tidak dapat diperkirakan. Dalam hal ini jumlah responden yang wawancarai adalah 10 orang untuk setiap daerah asal dan tujuan (setelah dilakukan penelitian awal, maka terdapat 52 pasang daerah asal dan tujuan, sehingga jumlah responden yang dijadikan sampel adalah 1040 orang (520 dikalikan 2).Jumlah sampel yang ditetapkan tidak melanggar persyaratan mengenai jumlah sampel minimum seperti yang dijelaskan oleh ahli statistik, yaitu: menurut (Gay, L.R dan Dhiel, 1992) yaitu minimal 30, menurut Sekaran, (Sekaran, 2006) yaitu minimal 30-500 atau $10 \times$ jumlah variabel (dalam hal ini variabel $8=10 \times 8=$ 80), dan menurut (Fraenkel et al., 2012) yaitu minimal 50 . Jadi jumlah sampel yang diambil sebesar 1040 telah memenuhi persyaratan sampel minimum. Metode pengambilan sampel yang digunakan adalah metode Judgment Sampling yaitu sampel dipilih berdasarkan penilaian peneliti bahwa responden adalah pihak yang paling baik untuk dijadikan sampel.

Model yang digunakan untuk menganalisa mobilitas penduduk antar daerah di provinsi Sumatera Barat ini diturunkan dari model Gravitasi yang telah diuraikan dalam Tinjauan Pustaka sebelumnya. Model tersebut dimodifikasi sesuai dengan variable yang dianalisis dalam penelitian ini sebagai berikut:

$\mathrm{FPAW}=\mathrm{c}_{0} \frac{(\mathrm{TP})^{\mathrm{c} 1} \cdot(\mathrm{UMR})^{\mathrm{c} 2} \cdot(\mathrm{SPKJ})^{\mathrm{c} 3}}{(\mathrm{PTKD})^{\mathrm{c} 4}}$

Persamaan (2) dapat diubah menjadi persamaan linear dengan menjadikan dalam bentuk log sebagai berikut : 
$\operatorname{LogFPAW}=\log \mathrm{c}_{0}+\mathrm{c}_{1} \log \mathrm{TP}+\mathrm{c}_{2} \log \mathrm{UMR}+\mathrm{c}_{3} \log \mathrm{SPKJ}-\mathrm{c}_{4} \log \mathrm{PTKDT}+\mathrm{E}_{\mathrm{ij}}$

Dimana :

FPAW = Frekwensi perjalanan yang dilakukan oleh responden antar wilayah asal dan wilayah tujuan (mewakili mobilitas penduduk tidak permanen antar wilayah).

UMR = Umur responden pada saat diwawancarai.

$\mathrm{TP}=$ Tingkat Pendidikan responden pada saat diwawancarai.

SPKJ = Status Pekerjaan responden pada saat diwawancarai.

PTKDT = Pengeluaran untuk Biaya Transportasi ke Daerah Tujuan

$\mathrm{c}_{0} \quad=$ konstanta,

$\mathrm{c}_{1} \ldots \mathrm{c}_{4} \quad=$ koefisien regressi yang akan ditaksir.

$\mathrm{E}_{\mathrm{ij}} \quad=$ error terms

Definisi operasional daripada variabel-variabel yang digunakan dalam penelitian ini adalah sebagai berikut :1). Frekwensi perjalanan antar wilayah adalah jumlah perjalanan yang dilakukan oleh responden dari wilayah asal ke wilayah tujuan pada tahun t, yang diukur dalam satuan kali perjalanan. 2). Umur adalah umur responden pada waktu diwawancarai yang diukur dalam tahun. 3). Tingkat pendidikan adalah tingkat pendidikan responden pada saat diwawancarai, yang diukur dengan memberikan bobot yaitu: 6 untuk tamat S3, 5 untuk tamat S2, 4 untuk tamat S1dan Diploma, 3 untuk tamat SMA , 2 untuk SMP dan 1 untuk tamat SD/Tidak sekolah. 4). Status pekerjaan adalah status pekerjaan responden pada saat diwawancarai. Bila tidak bekerja $=0$, Bekerja di daerah asal $=1$, mencari kerja $=2$, mahasiswa $=3$ dan bekerja di daerah tujuan $=4$. 5). Pengeluaran untuk Biaya Transportasi ke Daerah Tujuan yang diukur dalam rupiah.

Uji Instrumen Penelitian. Uji validitas digunakan untuk melihat kelayakan butir-butir pertanyaan dalam kuisioner tersebut dapat mendefinisikan suatu 
variabel. Menurut (Arikunto, 2013) persyaratan bagi sebuah test instrumen penelitian, yaitu validitas dan reliabilitas. Dalam hal ini validitas lebih penting, dan reliabilitas ini perlu, karena menyokong terbentuknya validitas. Sebuah tes mungkin reliabel tetapi tidak valid. Sebaliknya, sebuah tes yang valid biasanya reliabel.

Valid tidaknya suatu item instrumen dapat diketahui dengan membandingkan indeks korelasi product moment Pearsondengan level signifikansi 5\% dengan nilai kritisnya, bila nilai korelasi lebih besar dari 0.3 maka dinyatakan valid dan sebaliknya dinyatakan tidak valid.

Rumus korelasi dapat dituliskan sebagai berikut (Arikunto, 2003) :

$$
\mathrm{r}_{\mathrm{xy}}=\frac{N \sum X Y-\left(\sum X\right)\left(\sum Y\right)}{\sqrt{\left(\mathrm{N} \sum_{X} 2-\left(X^{2}\right)\right)\left(\mathrm{N} \sum_{Y} 2-\left(Y^{2}\right)\right)}}
$$

Dimana :

$\mathrm{r}_{\mathrm{xy}}=$ skor korelasi

$\mathrm{n}$ = banyaknya sampel

$\mathrm{X}=$ skor item pertanyaan

$\mathrm{Y}=$ skor total item

Item yang valid pasti reliable, sebaliknya setiap item yang reliable belum tentu valid (Sugiyono, 2007). Yang diakui teruji adalah item yang valid karena item reliable hanyalan item yang valid saja. Jika dalam suatu pengujian ada item yang gugur, maka item tersebut perlu dibuang, dan uji item dilakukan lagi sampai diperoleh item yang semuanya valid.

Uji reliabilitas digunakan untuk mengetahui konsistensi alat ukur, apakah alat pengukur yang digunakan dapat diandalkan dan tetap konsisten jika pengukuran tersebut diulang. Ada beberapa metode pengujian reliabilitas 
diantaranya metode tes ulang, formula belah dua dari Spearman-Brown, formula Rulon, formula Flanagan, Cronbach's Alpha, metode formula KR-20, KR-21, dan metode Anova Hoyt. Dalam penelitian ini digunakan metode Alpha (Cronbach's). Metode alpha sangat cocok digunakan pada skor berbentuk skala (misal 1-4, 1-5) atau skor rentangan (misal 0-20, 0-50). Metode alpha dapat juga digunakan pada skor dikotomi (0 dan 1) dan akan menghasilkan perhitungan yang setara dengan menggunakan metode KR-20 dan Anova Hoyt.Uji signifikansi dilakukan pada taraf signifikansi 0,05 , artinya instrumen dapat dikatakan reliabel bila nilai alpha lebih besar dari r kritis product moment,atau kita bisa menggunakan batasan tertentu. (Ghozali, 2006) menyatakan criteria instrument yang memiliki realibilitas yang tinggi adalah jika nilai koefisien yang diperoleh > 0,60.

Rumus Alpha dapat dituliskan sebagai berikut (Arikunto, 2013):

$$
\mathrm{r}_{11}=\left[\frac{k}{k-1}\right]\left[1-\frac{\sum \sigma_{n}^{2}}{\sigma_{t}^{2}}\right]
$$

Dimana :

$$
\begin{array}{ll}
\mathrm{r}_{11} & =\text { reliabilitas instrument } \\
\mathrm{k} & =\text { banyaknya butir pertanyaan atau banyaknya item } \\
\sum \sigma_{n}^{2} & =\text { jumlah variasi butir } \\
\sigma_{t}^{2} & =\text { varians total. }
\end{array}
$$

Uji Asumsi Klasik.Uji normalitas bertujuan untuk mengetahui apakah residual data yang digunakan mempunyai distribusi normal atau tidak. Data yang baik memiliki distribusi normal atau mendekati normal. Normalitas dapat dideteksi dengan menggunakan uji Jarque-Bera (JB test) (Widarjono, 2005). Dalam Uji Normalitas Dengan Menggunakan Jarque-Bera Test kita dapat membandingkan nilai JB Test dengan nilai dari Tabel Chi-Square, data dikatakan normal apabila 
nilai JB-Test berada dibawah nilai Tabel Chi-Square $\left(\mathrm{X}^{2}\right)$, maka hipotesis yang menyatakan bahwa residual terdistribusi normal ditolak dan sebaliknya.

Uji Multikolinearitas. Uji ini bertujuan untuk mengetahui apakah terdapat hubungan yang sempurna atau hampir mendekati sempurna antara beberapa variabel bebas yang digunakan dalam persamaan regresi. Ada beberapa indikator yang dapat digunakan untuk mendeteksi multikolinearita yaitu: 1). Ketika $\mathrm{R}^{2}$ sangat tinggi tetapi tidak banyak variabel independen yang signifikan secara statistik atas dasar uji t. 2). Dengan uji koefisien korelasi, yaitu menghitung koefisien korelasi antar variabel independen. Apabila koefisiennya rendah, maka tidak terjadi multikolinearitas. Sebaliknya jika koefisiennya tinggi $(>0.9)$, maka terdapat multikolinearitas dalam model tersebut. 3). Cara lainnya adalah dengan melihat nilai Tolerance (TOL) dan Variance Inflation Factor (VIP). Tolerance $=1-r^{2}$. VIF $=1$-tolerance. Dimana $\mathrm{r}$ adalah koefisien korelasi antara variable dependen dengan variable independen lainnya. Bila VIF $>5$ menunjukkan kolinearitas yang tinggi artinya terdapat multikolinearitas.

Uji Autokorelasi. Salah satu cara menguji ada tidaknya autokorelasi adalah dengan menggunakan Durbin-Watson test. Nilai Durbin Watson test berkisar antara 0 sampai 4, kemudian diambil keputusan dengan dasar pengambilan keputusan sebagai berikut: 1). Jika $\mathrm{dU}<\mathrm{d}<4$-dU, maka tidak terdapat autokorelasi baik positif atau negatif. 2). Jika $d<d L$, maka terdapat autokorelasi positif. 3). Jika $d>$ 4-dL, maka terdapat autokorelasi negatif. 4). Jika $\mathrm{dL} \leq \mathrm{d} \leq \mathrm{dU}$ atau 4-dU $\leq \mathrm{d} \leq 4$ dL, maka daerah tersebut merupakan daerah keraguan-raguan, dimana pengujian tidak meyakinkan. 
Uji Heterokedastisitas. Heteroskedastisitas muncul apabila eror atau residual model yang diamati tidak memiliki varian yang konstan dari satu observasi ke obsevasi lainnya. Konsekuensi adanya heteroskedastisitas dalam model regresi adalah estimator yang diperoleh tidak efisien. Salah satu cara untuk mendeteksi adanya heteroskedastisitas adalah dengan menggunakan Uji Glejser (Glejser Test). Dengan uji Glejser (Glejser Test) ini apabila nilai p-value $<(5 \%$ atau $10 \%)$ maka terdapat Heteroskedastisitas. Apabila nilai p-value > ( $5 \%$ atau 10\%) berarti tidak terdapat Heteroskedastisitas.

Pengujian $\mathrm{R}^{2}$ (Koefisien Determinasi). Kegunaan koefisien determinasi adalah (Gujarati, 2003) : 1). Sebagai ukuran ketepatan / kecocokan garis regresi yang dibuat dari hasil estimasi terhadap sekelompok data hasil observasi. Semakin besar nilai $\mathrm{R}^{2}$, maka semakin bagus garis regresi yang terbentuk dan semakin kecil $\mathrm{R}^{2}$, maka semakin tidak tepat garis regresi tersebut mewakili data hasil observasi. 2). Untuk mengukur proporsi / presentase dari jumlah variasi yang diterangkan oleh model regresi atau untuk mengukur besar sumbangan dari variabel $\mathrm{X}$ terhadap variabel Untuk mengukur proporsi / presentase dari jumlah variasi yang diterangkan oleh model regresi atau untuk mengukur besar sumbangan dari variabel $\mathrm{X}$ terhadap variabel $\mathrm{Y}$.

Nilai koefisien determinasi mengukur besarnya perubahan variabel dependen yang disebabkan oleh perubahan variabel-variabel independen. Nilai koefisien determinasi yang diberi simbol $\mathrm{R}^{2}$ yang nilainya antara 0 dan 1.

Uji statistik t dilakukan untuk menunjukkan seberapa jauh pengaruh satu variabel penjelas atau independen secara individual dalam menerangkan variasi 
variabel dependen (Gazali, 2005). Cara melakukan uji $\mathrm{t}$ adalah dengan membandingkan nilai t-hitung dengan t- Tabel. Apabila nilai t-hitung > t- Tabel, berarti bahwa perubahan variabel independen secara individual berpengaruh terhadap perubahan variabel dependen dan begitu sebaliknya.

Uji ini pada dasarnya untuk menunjukkan apakah semua variabel bebas yang dimasukkan dalam model berpengaruh secara bersama-sama terhadap variabel terikat. Apabila F-hitung > F- Tabel, berarti bahwa perubahan variabel independen secara bersama-sama berpengaruh terhadap perubahan variabel dependen, dan begitu sebaliknya.

\section{HASIL DAN PEMBAHASAN}

Kuisioner yang digunakan untuk mengambil data primer telah dilakukan uji validitas dan reliabilitas. Dari uji validitas nilai korelasi Item Pendidikan (0.592), nilai korelasi item Pekerjaan (0.728) dan nilai korelasi item mobilitas (0.936). Ketiga nilai tersebut lebih besar dari 0.3 atau Valid (lihat lampiran 1). Nilai Cronbach's Alpha adalah 0.672 adalah lebih besar dari r Tabel (0.250), atau lebih besar dari 0.60, Jadi dapat disimpulkan kuisioner yang digunakan reliable.

Uji Normalitas. Salah satu uji normalitas yang dapat digunakan adalah metode Jarque Berra Test. Hasil uji normalitas data dengan metode Jarque Berra Test dapat dilihat pada Tabel 3. 
Tabel 3

Uji Normalitas Dengan Metode Jarque-Berra Test"

\begin{tabular}{lc}
\hline \multicolumn{1}{c}{ VARIABEL } & JARQUE-BERRA TEST \\
\hline LOGFPAW & 39.067631 \\
LOGTKP & 90.179094 \\
LOGUMR & 81.37176 \\
LOGSPKJ & 73.93948 \\
LOG PTKDT & 50.04036 \\
\hline
\end{tabular}

Catatan : Nilai Chi-Square $\left(\mathrm{X}^{2}{ }_{0.05}\right)$ df $1040=125.98649$

Sumber : Hasil Pengolahan Data (Lampiran 4).

Sebagai indikator data terdistribusi dengan secara normal adalah nilai Jarque Berra Test $<$ Tabel chi square $\left(x^{2}\right)$ Nilai Tabel chi square $\left.(x 2)=125.9869\right)$. Dalam Tabel 2, nilai Jarque Berra Test untuk masing-masing variabel independenden < dari nilai Tabel chi square (x2). Jadi dapat disimpulkan bahwa data yang digunakan dalam analisa terdistribusi secara normal.

Uji Autokorelasi .Untuk mengetahui apakah data yang digunakan dalam penelitian mengalami masalah autokorelasi, dapat digunakan digunakan uji Durbin Watson. Apabila nilai uji DW > dU maka itu berarti tidak ada masalah autokorelasi dan sebaliknya apabila nilai DW < dU, maka terdapat masalah autokorelasi. Setelah dilakukan uji DW, ternyata diperoleh nilainya sebesar 1.35(lihat lampiran 3).Nilai $\mathrm{dL}=1.59$. Jadi $\mathrm{DW}<\mathrm{dL}$, ini mengindikasikan terjadinya masalah autokorelasi dalam data yang digunakan. Untuk mengatasi masalah autokorelasi tersebut, maka harus dilakukan regressi ulang dengan menggunakan data first difference. Setelah dilakukan regeressi ulang, diperoleh nilai DW test sebesar 2.80(lihat Lampiran 
7).Nilai DW > 4-dU yaitu : $2.80>2.41$, jadi dapat disimpulkan tidak terdapat lagi masalah autokorelasi.

Uji Heterokedastisitas. Salah satu cara yang dapat dilakukan untuk mengetahui adanya heteroskedastisitas adalah dengan uji Glejser. Hasil uji heteroskedastisitas dengan uji Glejser dapat dilihat pada Tabel 4.

Tabel 4.

Hasil Uji Heteroskedastisitas

\begin{tabular}{lcll}
\hline Heteroskedasticity Test: Glejser & & \\
\hline F-statistic & 0.798121 & Prob. F(4,1034) & 0.5264 \\
Obs*R-squared & 3.198047 & Prob. Chi-Square(4) & 0.5252 \\
Scaled explained SS & 3.618650 & Prob. Chi-Square(4) & 0.4601 \\
\hline
\end{tabular}

Sumber : Hasil Pengolahan Data (Lampiran 6).

Setelah dilakukan uji heteroskedastisitas dengan uji Glejser diperoleh nilai Probabilitas dari Chi-Square sebesar 0.5252 Nilai ini lebih besar dari 0.05, oleh karena itu dapat disimpulkan tidak terdapat heteroskedastisitas dalam model tersebut.

Uji Multikolinearitas. Salah satu cara untuk mengetahui adanya multikolinearitas adalah dengan menggunakan uji korelasi antar variabel independen. Jika uji korelasi antar variabel dependen $>0.9$ maka itu mengindikasikan terjadinya multikolinearitas. Sebaliknya jikan nilai uji korelasi antara variabel dependen $<0.9$ maka itu mengindikasikan tidak terjadi masalah multikolinearitas. Dalam Tabel 5 dapat dilihat bahwa nilai korelasi antara variabel independen $<0.9$. Oleh karena itu dapat kita simpulkan tidak terdapat masalah multikolinearitas antara variavel independen. 
Tabel 5.

Hasil Uji Korelasi

\begin{tabular}{cccccc}
\hline & LOGFPAW & LOGTP & LOGUMR & LOGSPKJ & LOGPTKDT \\
\hline LOGFPAW & 1 & & & & \\
LOGTP & 0.21 & 1 & & & \\
LOGUMR & -0.25 & -0.06 & 1 & & \\
LOGSPKJ & 0.39 & 0.43 & -0.24 & 1 & \\
LOGPTKDT & -0.58 & 0.02 & 0.02 & -0.04 & 1 \\
\hline Sumber $:$ Hasil Pengolahan Data (Lampiran 5) & & &
\end{tabular}

Setelah dilakukan uji asumsi klasik, maka dilakukan regressi. Hasil regressi faktor-faktor yang mempengaruhi mobilitas penduduk antar provinsi di Sumatera Barat dengan data sekunder dapat diringkaskan pada Tabel 6.

Tabel 6.

Hasil Regressi

\begin{tabular}{lccc}
\hline \multicolumn{1}{c}{ Variabel dependen: } & DLOGFPAW & & \\
\hline KONABEL & $\begin{array}{c}\text { KOEFISIEN } \\
\text { REGRESSI }\end{array}$ & $\begin{array}{c}\text { PROBABI- } \\
\text { LITAS }\end{array}$ & $\begin{array}{c}\text { SIGNIFI- } \\
\text { KANSI 0.05\% }\end{array}$ \\
DLOGTP & 0.000334 & 0.9786 & Tidak Signifikan \\
DLOGUMR & 0.064953 & 0.3900 & Tidak Signifikan \\
DLOGSTPKJ & -0.319648 & 0.0001 & Signifikan \\
DLOGPTKDT & 0.633964 & 0.0000 & Signifikan \\
\hline Koefisien Adjusted & -1.045944 & 0.0000 & Signifikan \\
R $^{2}$ & 0.4162 & \\
Durbin-Watson & & & \\
Stat & 2.8099 & \\
F-statistic & 186.0338 & Signifikan \\
Prob(F-statistic) & 0.000000 & \\
Sumber $:$ Hasil Pengolahan Data (Lampiran 7). &
\end{tabular}

Dalam Tabel 6 terlihat nilai Adjusted R sebesar 0.4162, ini berarti bahwa 41.62 persen variasi Frekwensi Perjalanan Antar Wilayah di Provinsi Sumatera Barat disebabkan oleh variasi Tingkat Pendidikan, Umur, Status Pekerjaan dan Pengeluaran untuk biaya transportasi ke daerah tujuan. Selebihnya disebabkan oleh variasi variabel lain yang tidak diteliti dalam model tersebut). 
Nilai konstanta sebesar 0.000334 berarti bahwa tanpa adanya variasi tingkat pendidikan, umur, status pekerjaan dan pengeluaran biaya transportasi ke daerah tujuan, maka besarnya frekwensi perjalanan antara daerah asal dengan daerah tujuan (migrasi tidak permanen) adalah sebesar 1 kali (penyederhanaan dari 1.0007693592 yang merupakan antilog dari 0.000334).

Nilai koefisien regresi Tingkat Pendidikan adalah sebesar 0.064953. Ini berarti bahwa apabila terjadi variasi Tingkat Pendidikan sebesar 1 persen akan meningkatkan frekwensi perjalananan antar wilayah (migrasi tidak permanen) di Provinsi Sumatera Barat sebesar 0.064953 persen. Sedangkan nilai probabilitas sebesar 0.39 berarti bahwa variasi tingkat pendidikan tidak berpengaruh secara signifikan terhadap variasi frekuensi perjalanan antar wilayah (migrasi tidak permanen) di Provinsi Sumatera Barat dengan derajat keberartian 0.05\%. Dari hasil analisis regressi ternyata tingkat pendidikan tidak berpengaruh secara signifikan terhadap frekwensi perjalanan antar wilayah (migrasi tidak permanen) di Provinsi Sumatera Barat. Hal ini tidak sejalan dengan hasil temuan penelitian terdahulu (Zhu, 2002), (Chotib, 2002) yang menemukan bahwa tingkat pendidikan berpengaruh terhadap keinginan untuk bermigrasi. Hal ini terjadi karena dalam penelitian ini migrasi yang dimaksud adalah migrasi tidak permanen, sedangkan dalam penelitian oleh peneliti terdahulu migrasi yang dimaksudkan adalah migrasi permanen. Jadi untuk migrasi non permanen tingkat pendidikan tidak berpengaruh terhadap keinginan untuk melakukan migrasi. Sedangkan untuk migrasi permanen keinginan untuk bermigrasi akan dipengaruhi oleh tingkat pendidikan. 
Koefisien regresi variabel umur adalah sebesar -0.319648. Ini berarti apabila terjadi variasi umur sebesar 1 persen, maka akan menurunkan frekuensi perjalanan antar wilayah di Provinsi Sumatera Barat sebesar 0.319648 persen. Sementara itu nilai probabilitas variabel umur sebesar 0.0001 berarti bahwa variabel umur berpengaruh terhadap variasi frekuensi perjalanan antar wilayah di Provinsi Sumatera Barat pada derajat keberartian 0.05\%. Hasil penelitian ini sejalan dengan penelitian yang dilakukan oleh (Sasmi, 2014) yang juga menemukan bahwa variable umur berpengaruh terhadap migrasi masuk ke kota Padang. Hasil penelitian ini juga sejalan dengan penelitian (Putrawan, I, W., 2015) yang menemukan bahwa variable umur mempengaruhi mobilitas non permanen penduduk Denpasar, Badung, Gianyar dan Tabanan Provinsi Bali. Masyarakat yang lebih muda lebih cendrung untuk melakukan mobilitas non permanen untuk mencari pekerjaan karena mereka masih kuat.

Sedangkan koefisien regresi variabel status pekerjaan) sebesar 0.633964 berarti bahwa apabila terjadi variasi variabel status pekerjaan sebesar 1 persen akan meningkatkan frekuensi perjalanan antar wilayah ( migrasi tidak permanen) di Provinsi Sumatera Barat sebesar 0.633964 persen. Sedangkan nilai probabilitasnya variabel status pekerjaan sebesar 0.0000 berarti bahwa variasi variabel status pekerjaan berpengaruh secara signifikan terhadap frekuensi perjalanan antar wilayah ( migrasi tidak permanen) di Provinsi Sumatera Barat pada derajat keberartian $0.05 \%$. Hasil penelitian ini sejalan dengan penelitian yang dilakukan oleh (Badiani, R., \& Safir, A., 2008) yang menemukan bahwa status pekerjaan berpengaruh tehadap keinginan untuk bermigrasi. Namun ada sedikit perbedaan 
antara status pekerjaan yang dimaksud dalam penelitian ini dengan status pekerjaan yang dimaksudkan oleh Badiani dan Safir. Dalam penelitian ini status pekerjaan yang dimaksud adalah: menganggur atau bekerja, mencari pekerjaan, status mahasiswa/pelajar dan tidak sekolah. Sedangkan dalam penelitian Badiani dan Safir yang dimaksud dengan status pekerjaan adalah status pekerjaan di sektor pertanian dan pekerjaan disektor non pertanian.

Nilai koefisien regresi variabel pengeluaran untuk biaya transportasi ke daerah tujuan di Provinsi Sumatera Barat sebesar -1.045944 berarti bahwa apabila terjadi variasi variabel Pengeluranan untuk biaya transportasi ke daerah tujuan di Provinsi Sumatera Barat sebesar 1 persen menyebabkan penurunan Frekwensi Perjalanan Antar Wilayah di Provinsi Sumatera Barat sebesar 1.045944 persen. Sedangkan nilai probabilitasnya variabel pengeluranan untuk biaya transportasi ke daerah tujuan di Provinsi Sumatera Barat sebesar 0.0000 berarti bahwa variasi variabel pengeluranan untuk biaya transportasi ke daerah tujuan di Provinsi Sumatera Barat berpengaruh secara signifikan terhadap frekuensi perjalanan antar wilayah ( migrasi tidak permanen) di Provinsi Sumatera Barat dengan derajat keberartian $0.05 \%$. Mengenai pengaruh variabel tingkat pengeluaran ke daerah tujuan migrasi (biaya transportasi) ini belum ada yang menelitinya. Ini merupakan temuan baru dalam penelitian ini

Nilai F-Statistik sebesar 186.03 lebih besar daripada nilai F- Tabel (2.37) berarti bahwa secara bersama-sama variasi variabel tingkat pendidikan, variabel Umur, variabel status pekerjaan dan variabel pengeluranan untuk biaya transportasi ke daerah tujuan berpengaruh secara signifikan terhadap variasi variabel frekuensi 
perjalalan antar wilayah di Provinsi Sumatera Barat. Nilai Prob.(F-statistic) sebesar 0.000 menunjukkan bahwa keempat variabel bebas tersebut berpengaruh terhadap frekuensi perjalalan antar wilayah (migrasi tidak permanen) dengan derajat keberartian 0.05 persen.

\section{SIMPULAN DAN SARAN}

Berdasarkan hasil analisis dalam penelitian ini, maka simpulan yang diperoleh adalah variable umur, status pekerjaan dan pengeluaran transportasi ke daerah tujuan berpengaruh secara signifikan terhadap frekwensi perjalanan antar wilayah (migrasi tidak permanen) di Provinsi Sumatera Barat. Tingkat pendidikan tidak berpengaruh secara signifikan terhadap frekwensi perjalan antar wilayah. (migrasi tidak permanen) di Provinsi Sumatera Barat.

Berdasarkan simpulan di atas, saran yang dapat direkomendasikan adalah Pertama, pemerintah Provinsi Sumatera Barat untuk meningkatkan kualitas jalan yang menghubungkan antar wilayah untuk memperlancar mobilitas penduduk antar wilayah. Kedua, Pemerintah perlu membangun jalan-jalan alternatif agar menghindari kemacetan yang sering terjadi pada akhi pekan karena banyaknya mobilitas penduduk antar wilayah, terutama rute antara Padang-BukittinggiPayakumbuh. Ketiga, Pemerintah perlu memperhatikan trayek-trayek yang armada angkutannya sudah using agar dapat diremajakan demi kelancaran dan kenyamanan bagi penduduk yang melakukan migrasi tidak permanen. 


\section{REFERENSI}

Arikunto. (2013). Prosedur Penelitian: Suatu Pendekatan Praktik. Rineka Cipta.

Arikunto, S. (2003). Prosedur Penelitian, Suatu Praktek. Bina Aksara.

Bachmeier, J, D., \& Bean, F. D. (2009). Cumulative Causation and Patterms of Mexican Immigration tu U.S. Metropolitan Destinations (27 September - 2 October).

Bachtiar, N. (1990). Migrasi Internal di Sumatera Barat, Indonesia. Universitas Indonesia.

Badiani, R., \& Safir, A. (2008). Coping wiht Aggregate Shocks; Temporary Migration and Other Labor Responses to Climatic Shocks in Rural India (JEL Clasification 012, 015, 018).

Bobkova, B. (2012). Gravity model estimation using panel data - is logarithmic transformation advisable? In Master Thesis. ies.fsv.cuni.cz/default/file/download/id/19306

Casi, L. (2006). Enhancing trade through migration. a gravity model of the network effect. Network.

Chotib. (2002). Krisis Ekonomi dan Mobilitas Penduduk Indonesia. Media Ekonomi, 6(2), 31-42.

Deardorff, A. (1998). Determinants of Bilateral Trade: Does Gravity Work in a Neoclassical World? In The Regionalization of the World Economy (pp. 732). National Bureau of Economic Research, Inc. https://econpapers.repec.org/RePEc:nbr:nberch:7818

Fraenkel, J., Wallen, N., \& Hyun, H. (2012). HowToDesignAndEvaluateResearchInEducation.TT-1.

Gay, L.R dan Dhiel, P. . (1992). Research Methods for Bussiness and Management. Mac Millan Publishing Company.

Gazali, I. (2005). Aplikasi Analisis Multivariate dengan Program SPSS.

Ghozali, I. (2006). Aplikasi Analisis Multivariate dengan Program SPSS. Badan Penerbit Universitas Diponegoro.

Gujarati, D. (2003). Ekonometri Dasar. Terjemahan: Sumarno Zain. Erlangga.

Hossain, M. Z. (2001). Rural-Urban Migration in Bangladesh: A Micro-Level Study. Presentation in The Brazil IUSSP Conference, 1-24.

Karib, A. (1992). Migrasi Keluar Penduduk Sumatera Barat: Studi Kasus Koto Gadang. Universitas Indonesia. 
Mantra, I. B. (1985). Pengantar Studi Demografi. Nur Cahya.

Mantra, I. B. (2000). Demografi Umum. Pustaka Pelajar.

Putrawan, I, W., \& N. P. S. (2015). Mobilitas Non Permanen Menjadi Pilihan Sebagian Pekerja dalam Menghadapi Himpitan Ekonomi di Wilayah Denpasar, Badung, Gianyar dan Tabanan Provinsi Bali 2014. Piramida, XI(2), 59-67.

Ramos, R. (2016). Gravity models: A tool for migration analysis. IZA World of Labor, March, 1-10. https://doi.org/10.15185/izawol.239

Salfadri; Abubakar Hamzah; B S Nazamuddin; Sofyan Syahnur. (2015). The Interregional Trade of Agricultural Commodities in West Sumatera, Indonesia. Aceh International Journal of Social Sciences (2015) 4(1) 1-20, 4 (1).

Sasmi, Cici \& Bachtiar, N. (2014). Analisis migrasi internal di sumatera barat: suatu kajian faktor-faktor yang mempengaruhi migrasi masuk ke kota padang. Universitas Andalas.

Sasmi, C. \& N. B. (2014). Analisis Migrasi Internal di Sumatera Barat: Suatu Kajian Faktor-Faktor yang Mempengaruhi Migrasi Masuk ke Kota Padang.

Sekaran, U. (2006). Research Methods for Business,Metodologi Penelitian untuk bisnis, Terjemahan. Salemba Empat.

Sugiyono. (2007). Metodologi Penelitian Bisnis. Gramedia.

Tarigan, R. (2005). Ekonomi Regional Teori dan Aplikasi Edisi Revisi. Bumi Aksara.

Todaro, M.P., \& S. (2003). Pembangunan Ekonomi di Dunia ketiga (8th ed.). Erlangga.

Widarjono, A. (2005). Ekonometrika Teori dan Aplikasi Untuk Ekonomi dan Bisnis. Ekonisia Fakultas Ekonomi Universitas Islam Indonesia.

Widaryatmo. (2009). Karakterisitk Pekerja Pelaku Mobilitas Non Permanen Indonesia 2007. Universitas Indonesia.

Yunus, H. S. (2010). Metodologi Penelitian Wilayah Kontemporer. Pustaka Pelajar.

Zhao, Y. (1999). Labor Migration and Earnings Differences: The Case of Rural China. Economic Development and Cultural Change, 47(4), 767-782. https://doi.org/10.1086/452431

Zhu, N. (2002). The Impacts of Income Gaps on Migration Decisions in China. China Economic Review, 13, 213-230. https://doi.org/10.1016/S1043951X(02)00074-3 


\section{Lampiran 1 . Hasil Uji Validitas Data}

\begin{tabular}{|c|c|c|c|c|c|c|}
\hline \multicolumn{7}{|c|}{ Correltions } \\
\hline & & LogTKP & LOGUMR & LOGSPKJ & LOGPTKDT & LOGFPAW \\
\hline \multirow[t]{3}{*}{ LogTKP } & $\begin{array}{l}\text { Pearson } \\
\text { Correlation }\end{array}$ & 1 & $.661^{* *}$ & $.535^{\star *}$ & $.592^{\star \star}$ & $.556^{\star *}$ \\
\hline & Sig. (2-tailed) & & 000 & 000 & 000 & 000 \\
\hline & $\mathrm{N}$ & 56 & 56 & 56 & 56 & 56 \\
\hline \multirow[t]{3}{*}{ LOGUMR } & $\begin{array}{l}\text { Pearson } \\
\text { Correlation }\end{array}$ & $.661^{\star *}$ & 1 & $.737^{* *}$ & $.738^{\star \star}$ & $.768^{* *}$ \\
\hline & Sig. (2-tailed) & 000 & & 000 & 000 & 000 \\
\hline & $\mathrm{N}$ & 56 & 56 & 56 & 56 & 56 \\
\hline \multirow[t]{3}{*}{ LOGSPKJ } & $\begin{array}{l}\text { Pearson } \\
\text { Correlation }\end{array}$ & $.535^{\star *}$ & $.737^{\star \star}$ & 1 & $.539^{\star \star}$ & $.540^{* *}$ \\
\hline & Sig. (2-tailed) & 000 & 000 & & 000 & 000 \\
\hline & $\mathrm{N}$ & 56 & 56 & 56 & 56 & 56 \\
\hline \multirow[t]{3}{*}{ LOGPTKDT } & $\begin{array}{l}\text { Pearson } \\
\text { Correlation }\end{array}$ & $.592^{\star *}$ & $.738^{\star *}$ & $.539^{* *}$ & 1 & $.525^{\star *}$ \\
\hline & Sig. (2-tailed) & 000 & 000 & 000 & & 000 \\
\hline & $\mathrm{N}$ & 56 & 56 & 56 & 56 & 56 \\
\hline \multirow[t]{3}{*}{ LOGFPAW } & $\begin{array}{l}\text { Pearson } \\
\text { Correlation }\end{array}$ & $.556^{* *}$ & $.768^{* *}$ & $.540^{* *}$ & $.525^{\star *}$ & 1 \\
\hline & Sig. (2-tailed) & 000 & 000 & 000 & 000 & \\
\hline & $\mathrm{N}$ & 56 & 56 & 56 & 56 & 56 \\
\hline
\end{tabular}

Sumber: Hasil pengolahan data dengan Program SPSS Versi 16.0

Keterangan : - Nilai korelasi semua variabel lebih besar dari 0.3 (Valid)

\section{Lampiran 2. Hasil Uji Reliabilitas}

\section{Case Processing Summary}

\begin{tabular}{|l|r|r|}
\hline & $\mathrm{N}$ & \multicolumn{1}{|c|}{$\%$} \\
\hline Cases Valid & 56 & 100.0 \\
Excluded $^{\mathrm{a}}$ & 0 & 0 \\
Total & 56 & 100.0 \\
\hline
\end{tabular}

a. Listwise deletion base on all variables in the procedure

\section{Realibility Statistics}

\begin{tabular}{|r|r|}
\hline Cronbach"s Alpha & N of items \\
\hline .672 & 4 \\
\hline
\end{tabular}

Sumber : Hasil Pengolahan Data dengan Program SPSS Versi 16.0.

Keterangan: Nilai Cronbach's Alpha adalah 0.672 adalah lebih besar dari r Tabel (0.250). Atau lebih besar dari 0.60, Jadi dapat disimpulkan data adalah Reliabel. 
Salfadri Syamsuddin. Analisis Determinasi Migrasi Tidak Permanen Antar Daerah

Lampiran 3. Hasil Regressi Pengaruh Umur, Tingkat Pendidikan, Status Pekerjaan Dan Pengeluaran Biaya Transportasi Terhadap Mobilitas Penduduk Tidak Permanen Di Provinsi Sumatera Barat

Dependent Variable: LOGFPAW

Method: Least Squares

Date: 02/09/16 Time: 17:02

Sample: 11040

Included observations: 1040

\begin{tabular}{lcccc}
\hline \hline Variable & Coefficient & Std. Error & t-Statistic & Prob. \\
\hline \hline C & 5.744943 & 0.209792 & 27.38403 & 0.0000 \\
LOGTKP & 0.279388 & 0.087796 & 3.182253 & 0.0015 \\
LOGUMR & -0.638597 & 0.088436 & -7.220988 & 0.0000 \\
LOGSPKJ & 0.569661 & 0.047935 & 11.88397 & 0.0000 \\
LOGPTKDT & -0.939215 & 0.036254 & -25.90653 & 0.0000 \\
\hline \hline R-squared & 0.504042 & Mean dependent var & & 1.094505 \\
Adjusted R-squared & 0.502125 & S.D. dependent var & & 0.492851 \\
S.E. of regression & 0.347757 & Akaike info criterion & & 0.730172 \\
Sum squared resid & 125.1679 & Schwarz criterion & & 0.753956 \\
Log likelihood & -374.6896 & Hannan-Quinn criter. & & 0.739194 \\
F-statistic & 262.9671 & Durbin-Watson stat & & 1.354353 \\
Prob(F-statistic) & 0.000000 & & & \\
\hline \hline
\end{tabular}

Sumber : Hasil Pengolahan Data

Lampiran 4.Hasil Uji Normalitas Pengaruh Umur, Tingkat Pendidikan, Status Pekerjaan Dan Pengeluaran Biaya Transportasi Terhadap Mobilitas Penduduk Tidak Permanen Di Provinsi Sumatera Barat

\begin{tabular}{|l|c|c|c|c|c|}
\hline & LOGFPAW & LOGTKP & LOGUMR & LOGSPKJ & LOGPTKDT \\
\hline Mean & 1.094505 & 0.452083 & 1.552918 & 0.379091 & 4.259952 \\
\hline Median & 1.000000 & 0.477121 & 1.568202 & 0.301030 & 4.267013 \\
\hline Maximum & 2.459392 & 0.778151 & 1.826075 & 0.698970 & 4.903090 \\
\hline Minimum & 0.301030 & 0.000000 & 1.176091 & 0.000000 & 3.477121 \\
\hline Std. Dev. & 0.492851 & 0.136722 & 0.125839 & 0.257571 & 0.298075 \\
\hline Skewness & 1.322326 & -0.922151 & -0.684139 & -0.108961 & -0.481788 \\
\hline Kurtosis & 3.911293 & 4.815210 & 2.925000 & 1.712054 & 2.524291 \\
\hline & & & & & \\
\hline Jarque-Bera & 39.067631 & 90.179094 & 81.37176 & 73.93948 & 50.04036 \\
\hline Probability & 0.094234 & 0.062543 & 0.072653 & 0.102230 & 0.123610 \\
\hline & & & & & \\
\hline Sum & 1138.285 & 470.1662 & 1615.035 & 394.2546 & 4430.350 \\
\hline Sum Sq. Dev. & 252.3757 & 19.42193 & 16.45303 & 68.93037 & 92.31376 \\
\hline & & & & & \\
\hline Observa-tions & 1040 & 1040 & 1040 & 1040 & 1040 \\
\hline
\end{tabular}

Sumber : Hasil Pengolahan Data. 
Lampiran 5. Hasil Uji Multikolinearitas Pengaruh Umur, Tingkat Pendidikan, Status Pekerjaan Dan Pengeluaran Biaya Transportasi Terhadap Mobilitas Penduduk Tidak Permanen Di Provinsi Sumatera Barat

\begin{tabular}{|l|c|c|c|c|c|}
\hline & LOGFPAW & LOGTKP & LOGUMR & LOGSTPKJ & LOGPTKDT \\
\hline LOGFPAW & 1 & & & & \\
\hline LOGTKP & 0.205104837 & 1 & & & \\
\hline LOGUMR & -0.252187240 & -0.060681842 & 1 & & \\
\hline LOGSTPKJ & 0.3921195947 & 0.434544038 & -0.24018404 & 1 & \\
\hline LOGPTKDT & -0.581455211 & 0.020533781 & 0.02275606 & -0.03796405 & 1 \\
\hline
\end{tabular}

Sumber : Hasil Pengolahan Data.

Lampiran 6Hasil Uji Heteroskedastisitas Pengaruh Umur, Tingkat Pendidikan, Status Pekerjaan Dan Pengeluaran Biaya Transportasi Terhadap Mobilitas Penduduk Tidak Permanen Di Provinsi Sumatera Barat

Heteroskedasticity Test: Glejser

\begin{tabular}{lccc}
\hline \hline F-statistic & 0.798121 & Prob. F(4,1034) & 0.5264 \\
Obs*R-squared & 3.198047 & Prob. Chi-Square(4) & 0.5252 \\
Scaled explained SS & 3.618650 & Prob. Chi-Square(4) & 0.4601 \\
\hline \hline
\end{tabular}

Test Equation:

Dependent Variable: ARESID

Method: Least Squares

Date: 02/09/16 Time: 00:50

Sample: 21040

Included observations: 1039

\begin{tabular}{lcccc}
\hline \hline Variable & Coefficient & Std. Error & t-Statistic & Prob. \\
\hline \hline C & 0.306137 & 0.007976 & 38.38418 & 0.0000 \\
DLOGTP & 0.049650 & 0.048472 & 1.024318 & 0.3059 \\
DLOGUMR & 0.052912 & 0.051687 & 1.023701 & 0.3062 \\
DLOGSTPKJ & 0.009688 & 0.024817 & 0.390383 & 0.6963 \\
DLOGPTKDT & -0.025076 & 0.043297 & -0.579162 & 0.5626 \\
\hline \hline R-squared & 0.003078 & Mean dependent var & 0.306121 \\
Adjusted R-squared & -0.000779 & S.D. dependent var & 0.256981 \\
S.E. of regression & 0.257081 & Akaike info criterion & 0.125950 \\
Sum squared resid & 68.33776 & Schwarz criterion & 0.149752 \\
Log likelihood & -60.43115 & Hannan-Quinn criter. & 0.134980 \\
F-statistic & 0.798121 & Durbin-Watson stat & 1.639213 \\
Prob(F-statistic) & 0.526443 & & \\
\hline \hline
\end{tabular}

Sumber : Hasil Pengolahan Data 
Lampiran 7.Hasil Regressi Pengaruh Umur, Tingkat Pendidikan, Status Pekerjaan Dan Pengeluaran Biaya Transportasi Terhadap Mobilitas Penduduk Tidak Permanen Di Provinsi Sumatera Barat Berdasarkan data First Difference

Dependent Variable: DLOGFPAW

Method: Least Squares

Date: 02/09/16 Time: 17:26

Sample (adjusted): 21040

Included observations: 1039 after adjustments

\begin{tabular}{lcccc}
\hline \hline Variable & Coefficient & Std. Error & t-Statistic & Prob. \\
\hline \hline C & 0.000334 & 0.012427 & 0.026879 & 0.9786 \\
DLOGTKP & 0.064953 & 0.075526 & 0.860010 & 0.3900 \\
DLOGUMR & -0.319648 & 0.080536 & -3.969002 & 0.0001 \\
DLOGSTPKJ & 0.633964 & 0.038668 & 16.39501 & 0.0000 \\
DLOGPTKDT & -1.045944 & 0.067464 & -15.50378 & 0.0000 \\
\hline \hline R-squared & 0.418492 & Mean dependent var & 0.000000 \\
Adjusted R-squared & 0.416242 & S.D. dependent var & 0.524281 \\
S.E. of regression & 0.400572 & Akaike info criterion & 1.012954 \\
Sum squared resid & 165.9134 & Schwarz criterion & 1.036756 \\
Log likelihood & -521.2295 & Hannan-Quinn criter. & 1.021983 \\
F-statistic & 186.0338 & Durbin-Watson stat & \\
Prob(F-statistic) & 0.000000 & & & \\
\hline \hline
\end{tabular}

Sumber : Hasil Pengolahan Data 